J. Clin. Chem. Clin. Biochem.

Vol. 17, 1979, pp. 529-532

\title{
Radioimmunoassay of Nortestosterone and Related Steroids
}

\author{
By R. Hampl,
}

Research Institute of Endocrinology, Prague, Czechoslovakia,

J. Picha,

Research Institute of Animal Production, Prague-Uhrinèves,

B. Chundela,

Laboratory of Doping Control, Prague,

and

L. Stärka,

Research Institute of Endocrinology, Prague, Czechoslovakia

(Received October 30, 1978/January 3, 1979)

Summary: A radioimmunoassay of nortestosterone and related steroids, including its principal metabolites, is described and evaluated. Antisera against nortestosterone-17 $\beta$-hemisuccinate- and nortestosterone-3-carboxymethyloxime-bovine serum albumin were raised in goats. By using a mixture of such antisera with different selectivity, the cross-reactions of several naturally occurring steroids can be reduced. The method can be applied for the detection of nortestosterone in both unprocessed or hydrolyzed urine extracts and also in plasma. It has been used as a screening test for anabolics in doping control.

\section{Radioimmunoassay für Nortestosteron und verwandte Steroide}

Zusammenfassung: Für die Bestimmung von Nortestosteron, seine Metabolite und verwandte synthetische anabole Steroide wurde ein Radioimmunoassay ausgearbeitet. Antisera gegen Nortestosteron-17 $\beta$-hemisuccinatund gegen Nortestosteron-3-carboxymethyloxim-Rinderserumalbumin wurden an Ziegen gewonnen und für die Bestimmung in einem optimalen Gemisch verwendet. Die Kreużreaktion mit endogenen Steroiden kann auf diese Weise unterdrückt werden, so daß die Methode als ein Screeningtest für Anabolika vom Nortestosterontyp im nativen sowie hydrolysiẹten Harn und im Plasma für den Zweck der Dopingkontrolle verwendet werden kann.

\section{Introduction}

We recently reported a radioimmunoassay of $17 \alpha$ alkylated anabolic steroids suitable for doping control (1). Another large group of anabolics is relăted to $19=$ nortestosterone. This includes parentërally active nortestosterone and its $17 \beta$-hydroxyesters, as well as orally active $17 \alpha$-alkyl-19-norsteroids.

The radioimmunological methods so far described for the detection of these compounds, use rabbit (2) or sheep (3) antisera raised against nortestosterone-3carboxymethyloxime-bovine serum albumin conjugate. They suffer from unsatisfactory specifity, owing to the limited structural differences between nortestosterone and natural androgens. In order to enhance the selectivity of steroid radioimmunoassay, the use of the mixture of antisera obtained with two different immunogens has been suggested $(4,5)$. This approach has been applied in the present work. 


\section{Materials and Methods}

\section{Materials}

$\left[1,2,4(n)^{3} \mathrm{H}\right]$ Nortestosterone (17 $\beta$-hydroxy-19-nor-4-androsten3-one), specific radioactivity $1514 \mathrm{GBq} \cdot \mathrm{mmol}^{-1}$ from Radiochemical Centre, Amersham, England was purified by paper chromatography in the system cyclohexane/toluene/methanol/ water (volumes $9+1+8+2$ ). Nortestosterone $17 \beta$-hemisuccinate and 3-carboxymethyloxime were prepared according to Erlanger et al. (6). The identity of nortestosterone derivatives was confirmed by ultraviolet and infrared spectroscopy as described elsewhere (7). The conjugates with bovine serum albumin were prepared by the mixed anhydride method (6) with minor modifications as described earlier (1). The final steroid-albumin molar ratios in conjugates assessed from ultraviolet spectra were 23 and 21 for nortestosterone $17 \beta$-hemisuccinate and 3-carboxymethyloxime, respectively. Anabolic steroids were obtained from Schering A.G. (Berlin), Spofa (Czechoslovakia) and Ciba (Switzerland). Other non-radioactive steroids were purchased from Koch-Light (England). Helix pomatia digestive juice, prepared in our laboratory and containing a minimum $50000 \mathrm{I} . \mathrm{U} . / \mathrm{ml} \beta$-glucuronidase, was used for enzymatic hydrolysis of urine. Chemicals wêre of analytical grade; bidistilled solvents and silanized glassware were used for radioimmunoassay.

\section{Methods}

\section{Preparation of antisera}

Goats were immunized with each conjugate according to the immunization schedule described previously (1). The highest titre was achieved only 8 weeks after the first immunization with $17 \beta$-conjugate, and after 12 weeks for the immunization with the 3-conjugate. Goats were then killed and bled out, and the sera were lyophilized. The stock solution of combined antisera was prepared by mixing $125 \mu$ l of anti-nor-testosterone-17 $\beta$ hemisuccinate-bovine serum albumin with $250 \mu \mathrm{l}$ of anti-nortestosterone-3-carboxymethyl-oxime-bovine serum albumin, and dilution of the resulting mixture with $4.625 \mathrm{ml}$ of buffer (see further). Combined antisera were divided into $100 \mu \mathrm{l}$ portions and kept frozen at $-15^{\circ} \mathrm{C}$. Before use they were further diluted 50 -fold with buffer.

\section{Sample preparation}

Plasma or untreated urine were processed as follows: Plasma $(100 \mu \mathrm{l})$ or urine $(5 \mathrm{ml})$ was extracted with diethyl ether $(3 \mathrm{ml}$ and $5 \mathrm{ml}$, respectively), the organic phase was washed with saline $\left(9 \mathrm{~g} \cdot \mathrm{l}^{-1}\right)$ and decanted into reaction tubes. The extraction tubes were rinsed with ether $(1 \mathrm{ml})$ which was added to the main portion, and the solvent was evaporated.

When conjugated steroids were to be analyzed, the following procedure was applied: Urine $(0.5 \mathrm{ml}), 0.1 \mathrm{~mol} \cdot \Gamma^{1}$ sodium acetate buffer, $\mathrm{pH} 4.5(0.5 \mathrm{ml})$ and $\beta$-glucuronidase solution in buffer $(100 \mu l$, at least 5000 I.U.) were incubated overnight at $37^{\circ} \mathrm{C}$. After cooling, the mixture was extracted with diethyl ether $(5 \mathrm{ml})$. The ether extract was washed with $0.1 \mathrm{~mol} \cdot 1^{-1}$ $\mathrm{NaOH}$ in saline and then saline only $(1 \mathrm{ml}$ each) and an aliquot of the ether extract ( $1 \mathrm{ml}$, equivalent to $100 \mu$ l of urine) was transferred into reaction tubes and evaporated.

Simultaneously, a calibration curve of standard nortestosterone (usually $0,0.2,0.5,1,2,4$ and $8 \mathrm{ng}$ ) was worked up in the same way.

\section{Radioimmunoassay}

$\left.\mathrm{I}^{3} \mathrm{H}\right]$ Nortestosterone $(250 \mathrm{~Bq})$ and appropriately diluted mixture (see results, optimal dilution) of antisera in buffer ' $(100 \mu \mathrm{l}$ each) were added to dry residues of samples or standards, and the volume was adjusted to $0.5 \mathrm{ml}$ with buffer. $0.1 \mathrm{~mol} \cdot \mathrm{I}^{-1}$ sodium phosphate, $\mathrm{pH} 7.2$ containing $9 \mathrm{~g} \cdot \mathrm{l}^{-1}$ saline, $1.0 \mathrm{~g} \cdot \mathrm{I}^{-1}$ sodium azide and $1.0 \mathrm{~g} \cdot \mathrm{l}^{-1}$ bovine serum albumin was used. The samples were shaken on a Vortex mixer, incubated at $37^{\circ} \mathrm{C}$ with shaking for $30 \mathrm{~min}$, then left at $4^{\circ} \mathrm{C}$ for 1 hour. A cold, stirred suspension of dextran-coated charcoal $\left(0.5 \mathrm{ml}\right.$ of $2.5 \mathrm{~g} \cdot \mathrm{l}^{-1}$ Norit $\mathrm{A}$ and $0.25 \mathrm{~g} \cdot \mathrm{r}^{-1}$ Dextran 70 ) was added to each sample, the tubes were shaken briefly on a Vortex mixer, then left at $4^{\circ} \mathrm{C}$ for $10 \mathrm{~min}$. Following $10 \mathrm{~min}$ centrifugation at $2500 \mathrm{rpm}$ an aliquot of supernatant $(0.5 \mathrm{ml})$ was removed for determination of radioactivity. Radioactivity was measured on a Betaszint BF 5000 liquid scintillation spectrometer as described previously (1).

\section{Determination of binding characteristics of antisera}

The titre was expressed as the highest final dilution of serum at which more than $50 \%$ of given amount of labelled steroid $(250 \mathrm{~Bq})$ remained in the supernatant under the conditions of the assay. Apparent association constants were calculated from saturation curves obtained with nortestosterone as a ligand using a Scatchard plot corrected for non-specific binding (8). The specifity was evaluated from the ability of steroid competitors to crossreact with antibodies and their mixture. From the percentage of radioactivity remaining in the supernatant in the presence of competitor and respective amounts of the steroids, the log logit straight lines were constructed (9), each from at least five points. Hence, the amounts of steroids required for $50 \%$ displacement of tracer were determined.

\section{Results}

\section{Characterization of antibodies}

The highest antibody titres obtained from goats immunized with nortestosterone-17 $\beta$-hemisuccinate- and nortestosterone-3-carboxymethyloxime-bovine serum albumin conjugates were $1: 32000$ and $1: 8000$, respectively. The corresponding association constants with nortestosterone as a ligand at $25^{\circ} \mathrm{C}$ were $1.31 \times 10^{9} \mathrm{l} \cdot \mathrm{mol}^{-1}$ and $1.78 \times 10^{9} 1 \cdot \mathrm{mol}^{-1}$ respectively.

Cross-reactivities of 24 steroids with each antiserum are shown in the first two columns of table 1 . Three nortestosterone $17 \beta$-hydroxyesters, two $5 \alpha$-reduced metabolites, norethandrolone and four other orally active anabolic steroids, as well as several hormonal steroids (especially androgens) and their metabolites, were tested. As can be seen, both antibodies react with 19-norsteroids, but to different extents. The antibody raised against the $17 \beta$-conjugate recognized preferably those steroids possessing the $\Delta^{4}-3$-oxogrouping (nortestosterone $17 \beta$ hydroxyesters, testosterone, androstenedione, progesterone). Besides the hydrogen atom on $\mathrm{C}_{10}$ ("19-nor" group), a structural determinant for antibody against 3-conjugate appeared to be the $17 \beta$-hydroxy group, while the stereochemistry of the A-ring was less important; $17 \beta$-hydroxy-19-norsteroids, estradiol, testosterone and $17 \beta$-androstanediols were the most effective competitors.

\section{Determination of the optimal ratio of antisera in the mixture}

To minimize cross reactions of naturally occurring steroids and, at the same time, to retain the ability to bind 19-nor-compounds, the optimal composition of the mixture of both antisera was established according to Rodbard (5). 4-Androstene-3,17-dione and $5 \alpha$-androstane-3 $\alpha, 17 \beta$-diol were chosen as model compounds: the former cross-reacted considerably only with antibody against the $17 \beta$-conjugate (Ab. 1), whereas the latter showed high cross-reaction with antibody raised against the 3-oxime conjugate (Ab. 2) only. 
Various volumes of both antisera, each diluted so that a given amount of nortestosterone (1 ng) caused $50 \%$ displacement of tracer (1:12000 for Ab. 1 and 1:4000 for $A b .2$, respectively), were combined to obtain the following mixtures: 1.0 Ab. 1;0.7 Ab. $1+0.3 \mathrm{Ab} .2$; 0.5 Ab. $1+0.5$ Ab. 2; 0.3 Ab. $1+0.7$ Ab. 2; 1.0 Ab. 2 . The amounts of nortestosterone and both competitors required for $50 \%$ displacement of radioactive tracer ("ID 50 and $\mathrm{ED}_{50}$ ", respectively, according to Rodbard (5)) were then established with each mixture. The ratios $\mathrm{ED}_{50} / \mathrm{ID}_{50}$ for both model compounds were calculated and plotted against relative composition of the antiseramixture. As shown on figure 1, two straight lines were obtained, their intercept giving the optimal composition of the mixture. The value found was $0.60 \mathrm{Ab} .1$ and $0.40 \mathrm{Ab}$. 2. It corresponded to two volumes of undiluted $A b .2$ and one of $A b$. 1, further diluted to the working dilution as described in methods.

The cross reactivities of the steroids under study with the optimal antibody mixture are shown in the third column of table 1 .

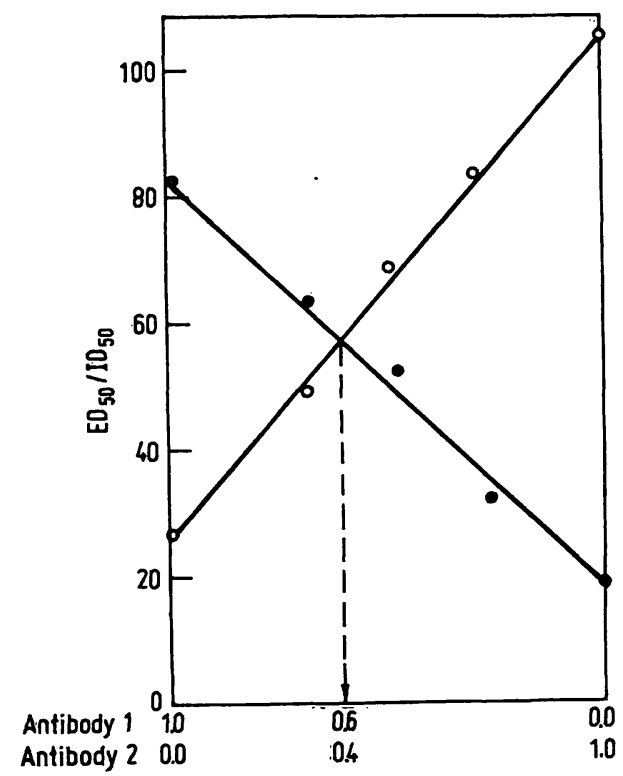

Fig. 1. Determination of the optimal ratio of antisera in the mixture. Ratios $\mathrm{ED}_{50} / \mathrm{ID}_{50}$ (where $\mathrm{ED}_{50}$ means the amount of the competitor and $\mathrm{ID}_{50}$ amount of nortestosterone, respectively, required for $50 \%$ displacement of radioactive tracer) were plotted against the relative composition of antisera-mixture. Open circles: $\mathrm{ED}_{50}$ of androstenedione/ $\mathrm{ID}_{50}$, full circles: ED 50 of $5 \alpha$-androstane-3 $\alpha, 17 \beta$-diol/ID 50 .

Añtibody 1: Antiserum with antibodies against nortestosterone17 $\beta$-hemisuccinate-bovine serum albumin conjugate

Antibody 2: Antiserum with antibodies against nortestosterone3-carboxymethyloxime-bovine serum albumin conjugate

a) goat anti-nortestosterone-17 1 -hemisuccinate bovine serum albumin

b) goat anti-nortestosterone-3-carboxymethyloxime bovine serum albumin

c) synthetic estrogen
Tab. 1. Cross-reactivities of various steroids with goat nortestosterone antibodies and their mixtures.

\begin{tabular}{|c|c|c|c|}
\hline \multirow[t]{2}{*}{ Steroid (systematic name) } & \multicolumn{3}{|c|}{ Cross-reaction in $\%$} \\
\hline & Ab. $1^{a)}$ & Ab. $2^{\text {b) }}$ & $\begin{array}{l}\text { Ab. } 1+\text { Ab. } 2 \\
0.6 \quad 0: 4\end{array}$ \\
\hline
\end{tabular}

Nortestosterone and its analogues

Nortestosterone (17 $\beta$ -

hydroxy-19-nor-4-andro-

sten-3-one)

Nortestosterone phenylpropionate

Nortestosterone acetate

Nortestosterone hemi-

succinate

Nordihydrotestosterone

(17 $\beta$-hydroxy-19-nor-5 $\alpha$ -

androstan-3-one)

$5 \alpha$-androstane-19-nor-3,

$17 \beta$-diol

$\begin{array}{ccc}100 & 100 & 100 \\ 10.1 & 1.73 & 5.02 \\ 30.2 & 2.81 & 19.2 \\ 18.9 & 2.50 & 10.5 \\ 21.4 & 80.7 & 27.4 \\ & & \\ 0.46 & 20.4 & 8.26 \\ 37.6 & 5.40 & 29.9\end{array}$

Norethandrolone $(17 \alpha$ ethyl-17 $\beta$-hydroxy-19nor-4-androsten-3-one)

Other anabolic steroids

Drostanolone ( $2 \alpha$-methyl-

$17 \beta$-hydroxy-5 $\alpha$-androstan3-one)

Methandienone (17 $\alpha$-methyl$17 \beta$-hydroxy-1,4-androstadien-3-one)

Methenolone (1-methyl-17 $\beta$ hydroxy-5 $\alpha$-androst-1-en-3one)

Stanazolol ( $17 \alpha$-methyl-17 $\beta$ hydroxy-5 $\alpha$-androstane-3,2C-pyrazol)

\section{Androgens and their} metabolites

Testosterone

Dihydrotestosterone

(17 $\beta$-hydroxy-5 $\alpha$ -

androstan-3-one)

Androstenedione (4-androstene-3,17-dione)

Androsterone ( $3 \alpha$-hydroxy$5 \alpha$-androstan-17-one)

Dehydroepiandrosterone ( $3 \beta$-hydroxy-5-androsten-17one)

Etiocholanolone ( $3 \alpha-$

hydroxy-5 $\beta$-androstan-

17-one)

$5 \alpha$-androstane- $3 \alpha, 17 \beta$-diol

$5 \beta$-androstane- $3 \alpha, 17 \beta$-diol

Epitestosterone $(17 \alpha-$ hydroxy-4-androsten-3-one)

Other hormonal steroids Cortisol

Estradiol

Progesterone

$\begin{array}{lll}3.86 & 0.93 \quad 1.83\end{array}$

$0.30<0.1 \quad 0.11$

$0.40<0.1$

Ethinylestradiol $(17 \alpha$ ethinyl-1,3,5 (10) estratriene3,17 $\beta$-diol $\left.{ }^{c}\right)$ 


\section{Reliability criteria of the method}

Accuracy was expressed as recovery of nortestosterone added to urine and/or plasma samples processed as described under methods. For each group representing six analyses the respective coefficients of variation were also calculated (precision). The results for untreated and hydrolyzed urine are summarized in table 2 , for plasma in table 3 .

Sensitivity was determined according to Ekins (10), as the lowest amounts of nortestosterone added to urine or plasma samples which could be detected with $95 \%$ probability. The respective values for untreated urine, hydrolyzed urine and plasma were 287,329 and $22 \mathrm{pg}$.

\section{Discussion}

Compared with the radioimmunoassay of $17 \alpha$-alkylated anabolic steroids, the detection of nortestosterone and its metabolites presents further problems. These arise from similarities in structure and metabolism between nortestosterone and natural androgens, namely testosterone (11).

When nortestosterone 3-carboxymethyloxime conjugate only is used as an immunogen, considerable cross-reaction of various $17 \beta$-hydroxysteroids occurs, whereas detection of 19-norcompounds without a free $17 \beta$ hydroxy group (nortestosterone esters, 17-oxo-19norsteroids) is limited.

In this work, the aim was to increase group selectivity as needed in screening methods in doping control for anabolics. Using the mixture of antisera elicited by two different immunogens the undesired cross-reaction of several steroids can be reduced without considerable loss of ability to detect nortestosterone analogues. The only hormone, the cross-reaction of which cannot be overcome, is testosteroné.

The reliability criteria of the method described are comparable with common radioimmunoassay procedures. It was applied successfully in doping control for anabolics at the European athletics championship, Prague 1978. Both unprocessed and hydrolyzed urine extracts were used in the assay. 5-6 Control urine samples were analyzed within each series. Those values which were higher by 2.S.D. from the mean of controls were considered as positive.

Tab. 3. Accuracy and precision of nortestosterone radioimmunoassay in plasma. Increasing amounts of nortestosterone were added to normal male plasma, which was processed as described in methods. Six determinations were carried out in each group.

\begin{tabular}{|c|c|c|c|}
\hline $\begin{array}{l}\text { Nortestosterone } \\
\text { added }\end{array}$ & $\begin{array}{l}\text { found } \\
\text { mean } \pm \text { S.D. } \\
\text { pg }\end{array}$ & $\begin{array}{l}\text { Coefficient } \\
\text { of variation } \\
\%\end{array}$ & $\begin{array}{l}\text { Recovery } \\
\%\end{array}$ \\
\hline $\begin{array}{l}\text { none } \\
50 \\
100 \\
200\end{array}$ & $\begin{aligned} & 120 \pm 10.9 \\
& 172 \pm 16.0 \\
& 209 \pm 18.3 \\
& 284 \pm 28.5 \\
& \text { mean }:\end{aligned}$ & $\begin{array}{r}9.8 \\
9.30 \\
8.76 \\
10.04 \\
9.30\end{array}$ & $\begin{array}{r}- \\
101.2 \\
95.0 \\
88.8 \\
95.0\end{array}$ \\
\hline
\end{tabular}

Tab. 2. Accuracy and precision of nortestosterone radioimmunoassay in urine. Increasing amounts of nortestosterone were added to normal male urine, which was further processed as described in methods. Untreated and/or enzymatically hydrolyzed urine samples were analyzed, with six determinations in each group.

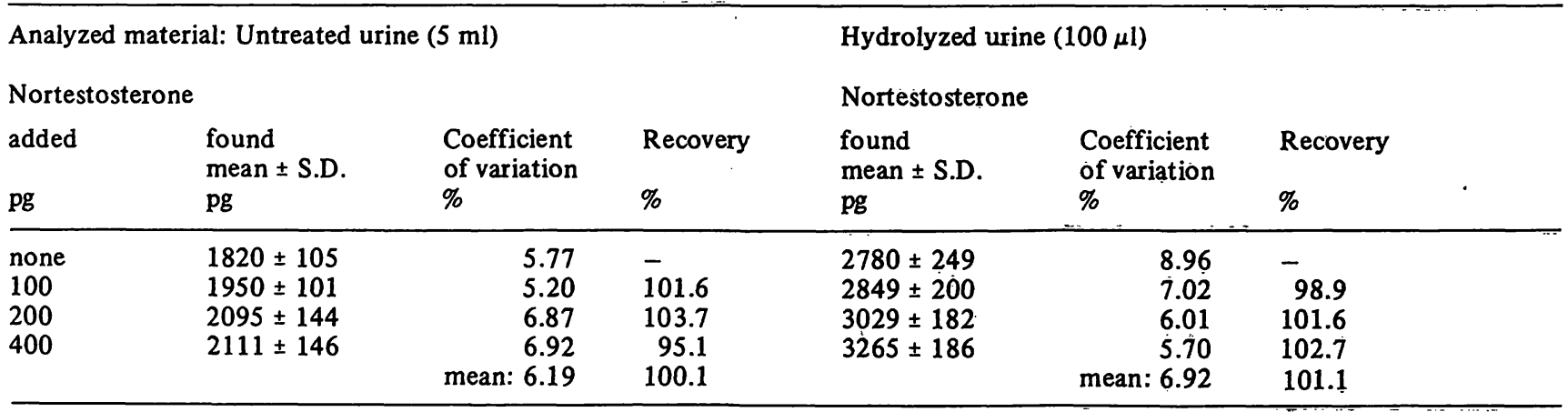

\section{References}

1. Hampl, R., Pícha, J., Chundela, B. \& Stárka, L. (1978), J. Clin. Chem. Clin. Biochem. 16, 279-282.

2. Brooks, R. V., Firth, R. G. \& Sumner, N. A. (1975), Brit. J. Sport. Med. 9, 89-92.

3. Jondorf, W. R. (1977), Xenobiotica 7, 671-681.

4. Sekihara, H. \& Ohsawa, N. (1974), Steroids 24, 317-336.

5. Rodbard, D. (1977), Steroids 29, 149-160.

6. Erlanger, B. F., Borek, F., Beiser, S. M. \& Lieberman, S. (1959), J. Biol. Chem. 234, 1090-1094.

7. Hampl, R., Pícha, J., Chundela, B., Stránská, I. \& Stárka, L. (1978), Radiochem. Radioanal. Lett. 34, 301-306.
8. Chamness, G. C. \& McGuire, W. L. (1975), Steroids 26, 538-542.

9. Rodbard, D., Bridison, W. \& Rayford, P. L. (1969), J. Lab. Clin. Med. 74, 770-781.

10. Ekins, R. \& Newman, B. (1970), Acta Endocrinol. (Copenhagen.) Suppl. 14خे, 11-36.

11. Ward, R, J., Shackleton, C. H. L. \& Lạwson, A. M. (1975), Brit. J. Sport. Med. 9, 93-97.

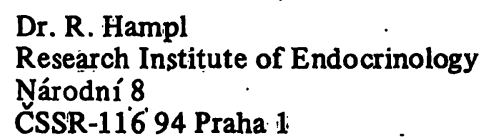




\section{Walter de Gruyter Berlin-New York}

W. Schwemmler

\section{Mechanismen der Zellevolution}

Grundriß einer modernen Želltheorie

Format $17 \mathrm{~cm} \times 24 \mathrm{~cm}$. 276 Seiten. 120 Abbildungen und 30 Tabellen (davon 6 in Farbe). 1 Klapptafel. Umfangreiches Glossar. Ausführliches Literaturverzeichnis. 1978. Plastik flexibel DM 42,- ISBN 3110067765

Der Autor stellt den GrundriB einer modernen Zelltheorie vor. Dabei versucht er, den Gesamtkomplex Evolution in seiner kosmischen, chemischen, biologischen und ansatżweise kulturellen Dimension dem naturwissenschaftlich interessierten Leser verständlich zu machen. Zu diesem Zweck werden alle verfügbaren experimentellen und theoretischen Daten herangezogen. Sie werden, wenn auch nicht quantitativ, so doch in ihrer qualitativen Aussage voll ausgeschöpft.

Die Darstellung der Daten selbst erfolgt nicht durch bloßes Aneinanderreihen, sondern durch Herausstellen elementarer Zusammenhänge. Dies findet in der Aufstellung verständlicher Systeme und Modelle sichtbarsten Ausdruck. Die Evolutionsphänomene werden folglich nicht nur beschrieben und erklärt, sondern auch systematisiert und in ein allgemeines Evolutionskonzept eingeordnet. Das wesentliche Ergebnis ist die Ableitung der Periodizität evolvierender Systeme wie unter anderem ein hypothetisches „Periodensystem der Zellen“.

Das Buch trägt also nicht nur dem Bedürfnis nach einschlägiger Information über den ProzeB der Zellevolution Rechnung, sondern vermittelt gleichzeitig ein neues komplexes Evolutionsverständnis. Letżteres entspricht dem zentralen Bestreben der Wissenschaft, zu immer wirklichkeitsgetreueren, einheitlichen Modellvorstellungen der gesamten realen Welt zu gelangen. So gesehen ist die Abhandlung auch ein bescheidener Beitrag zur übergreifenden Modellbiologie bzw. Theoretischen Biologie. Angesichts anschwellender Datenfluten bestehen hierzu in steigendem Maße Bedürfnis und Notwendigkeit. 